\title{
Cytotoxic Granule Protein
}

National Cancer Institute

\section{Source}

National Cancer Institute. Cytotoxic Granule Protein. NCI Thesaurus. Code C116392.

A protein that is stored in the secretory granules of cytotoxic leukocytes and plays a role in cell-mediated cytolysis. 